\title{
IN VITRO ANTINEPHROLITHIASIS EFFECT OF BREADFRUIT (ARTOCARPUS ALTILIS (PARK) FOSBERG) LEAVES EXTRACT BY ATOMIC ABSORPTION SPECTROPHOTOMETRY
}

\author{
EFFENDY DE LUX PUTRA ${ }^{1}$, NAHITMA GINTING ${ }^{1}$, NAZLINIWATY NAZLINIWATY ${ }^{2}$, IKSEN IKSEN ${ }^{1}$, \\ ERIK KURNIAWAN ${ }^{1}$, NERDY NERDY ${ }^{*}$
}

\begin{abstract}
${ }^{1}$ Department of Pharmaceutical Chemistry, Faculty of Pharmacy, University of Sumatera Utara, Medan, Indonesia, 20155.
${ }^{2}$ Department of Pharmaceutical Technology, Faculty of Pharmacy, University of Sumatera Utara, Medan, Indonesia, 20155. Email: nerdy190690@gmail.com
\end{abstract}

Received: 07 March 2018, Revised and Accepted: 25 March 2018

\begin{abstract}
Objective: The objective of this study is to observe the solubility calcium oxalate as a prototype of kidney stone in breadfruit leaf extract solution (n-hexane extract solution, ethyl acetate extract solution, and ethanol extract solution) by atomic absorption spectrophotometry.

Methods: Research was conducted qualitatively to analyze calcium oxalate solubility in breadfruit leaf extract solution. The solubility of calcium was known by measuring the levels of calcium in extract solution before and after incubation with calcium oxalate. Potassium as a factor that can enhance the solubility of calcium oxalate also measured by atomic absorption spectrophotometry.
\end{abstract}

Results: The higher concentration of extract solution incubated with calcium oxalate, the higher dissolving activity of calcium oxalate. The highest activity was found in ethyl acetate extract to dissolve calcium oxalate. Potassium has a small effect on the activity of dissolving calcium oxalate. Activity may be due to the phytochemical content present in the ethyl acetate extract.

Conclusion: Ethyl acetate extract solution has the highest activity to dissolve calcium compared to n-hexane extract and ethanol extract solution.

Keywords: In vitro, Antinephrolithiasis, Artocarpus altilis, Atomic absorption spectrophotometry.

(C) 2018The Authors. Publishedby Innovare Academic Sciences PvtLtd. This is an open access article under the CC BY license (http://creativecommons. org/licenses/by/4. 0/) DOI: http://dx.doi.org/10.22159/ajpcr.2018.v11s1.26607

\section{INTRODUCTION}

Traditional medicine is one of nation cultural heritages that needs to be developed further to be utilized [1]. In some developing countries like Indonesia, that traditional medicine has been used to treat chronic diseases as an alternative of synthetic drugs [2]. The traditional medicine were safe and no toxic effect compared to synthetic medicine $[3,4]$. Infuse technique was commonly used in Indonesia which have several advantages such as cheaper, faster, and simple in producing.

Breadfruit is one of Moraceae families which is widely used in Indonesian society for disease treatment such as anti-inflammation, antiplatelet, antioxidant, antinephritis, antimicrobial, and antidiabetic and also maintains kidney function [5]. Breadfruit leaves contain a variety of phytochemical compounds including flavonoid, saponin, tannin, and steroid and various mineral such as potassium. The high content of potassium in breadfruit leaves is believed to dissolve calcium salts in kidney stones [6].

In Indonesia, the prevalence rate of kidney stones is 51.9 per 10.000 population with a risk of sufferer experienced by men than woman with ratio 3:1. Kidney stone is a stone in kidney duct which the main content of kidney stone was calcium oxalate, calcium phosphate, calcium carbonate, or the combination [7]. Modern treatment of kidney stones such as surgery or ultrasonic waves requires relative high cost so that traditional medicine is preferred to be used to prevent and dissolved kidney stones [8]. Therefore, this study will observe the solubility calcium oxalate as a prototype of kidney stone in breadfruit leaf extract solution (n-hexane extract solution, ethyl acetate extract solution, and ethanol extract solution) by atomic absorption spectrophotometry.

\section{MATERIALS AND METHODS}

Materials

Materials used in this research were breadfruit (Artocarpus altilis (Park) Fosberg) leaves, ammonium oxalate (Merck), demineralized water (Brataco), calcium chloride (Merck), nitric acid 65\% (Merck), standard solution of potassium $1000 \mathrm{mg} / \mathrm{mL}$, and the standard solution of calcium $1000 \mathrm{mg} / \mathrm{mL}$. Breadfruit (A. altilis (Park) Fosberg) leaf sample was identified at Herbarium Medanese, University of Sumatera Utara, Medan, Indonesia, 20155.

\section{Research design}

This test solution comprises seven groups: Four groups (A, B, C, and D) with incubation with calcium oxalate and three groups (E, F, and G) without incubation with calcium oxalate.

A: Demineralized water with incubation with calcium oxalate.

B: Breadfruit leaf $n$-hexane extract solution with incubation with calcium oxalate.

C: Breadfruit leaf ethyl acetate extract solution with incubation with calcium oxalate.

D: Breadfruit leaf ethanol extract solution with incubation with calcium oxalate.

E: Breadfruit leaf n-hexane extract solution without incubation with calcium oxalate.

F: Breadfruit leaf ethyl acetate extract solution without incubation with calcium oxalate.

G: Breadfruit leaf ethanol extract solution without incubation with calcium oxalate.

Groups B, C, D, E, F, and G divided into 5 different concentrations 1 $\% \mathrm{w} /{ }_{\mathrm{V}}, 2 \% \mathrm{w} /{ }_{\mathrm{v}}, 3 \% \mathrm{w} /{ }_{\mathrm{v}}, 4 \% \mathrm{w} /{ }$, and $5 \% \mathrm{w} / \mathrm{v}$ with the code B1 to B5, C1 to C5, D1 to D5, E1 to E5, F1 to F5, and G1 to G5. Each concentration repeated 6 times for treatment with incubation and without incubation.

\section{Preparation of breadfruit leaf extract}

Fresh breadfruit leaves cleaned and dried. Dried breadfruid leaves were extracted with graduated maceration methods. A total of $1 \mathrm{~kg}$ of dried breadfruid leaves was soaked with $10 \mathrm{~L}$ of $\mathrm{n}$-hexane (stirred it 
every day) for 5 days, filtered the mixture, and collected the filtrate. The residue was soaked again with $5 \mathrm{~L}$ of $\mathrm{n}$-hexane (stirred it every day) for 3 days, filtered the mixture, and collected the filtrate. The residue was soaked with $10 \mathrm{~L}$ of ethyl acetate (stirred it every day) for 5 days, filtered the mixture, and collected the filtrate. The residue was soaked again with $5 \mathrm{~L}$ of ethyl acetate (stirred it every day) for 3 days, filtered the mixture, and collected the filtrate. The residue was soaked with $10 \mathrm{~L}$ of ethanol (stirred it every day) for 5 days, filtered the mixture, and collected the filtrate. The residue was soaked again with $5 \mathrm{~L}$ of ethanol (stirred it every day) for 3 days, filtered the mixture, and collected the filtrate. Each dilute extract (n-hexane extract, ethyl acetate extract, and ethanol extract) was dried with rotary evaporator and water bath to obtained viscous extract.

\section{Preparation of breadfruit leaf extract solution}

A total of $10 \mathrm{~g}$ of each breadfruit leaf viscous extract (n-hexane extract, ethyl acetate extract, and ethanol extract) was dissolved in $100 \mathrm{~mL}$ of demineralized water and used as breadfruit leaf extract solution.

Preparation of breadfruit leaf extract solution with incubation with calcium oxalate

$50 \mathrm{~mL}$ of demineralized water for Group A and $50 \mathrm{~mL}$ of breadfruit leaf extract solution (n-hexane extract solution, ethyl acetate extract solution, and ethanol extract solution) for Groups B, C, and D, putted into $100 \mathrm{~mL}$ erlenmeyer, putted $50 \mathrm{mg}$ calcium oxalate, and incubated on $37^{\circ} \mathrm{C}$ for $1 \mathrm{~h}$ (stirred it every $10 \mathrm{~min}$ ). Filtered the solution, added $10 \mathrm{~mL} \mathrm{HNO}_{3} 65 \%$, and heated on a hotplate until the solution becomeS transpicuous.

\section{Preparation of breadfruit leaf extract solution without incubation} with calcium oxalate

$50 \mathrm{~mL}$ of each breadfruit leaf extract solution (n-hexane extract solution, ethyl acetate extract solution, and ethanol extract solution) for Groups $\mathrm{E}, \mathrm{F}$ and $\mathrm{G}$, putted into $100 \mathrm{~mL}$ erlenmeyer, added $10 \mathrm{~mL} \mathrm{HNO}_{3} 65 \%$, and heated on hotplate until the solution becomeS transpicuous.

\section{Preparation of calibration curve of potassium}

A total of $5 \mathrm{~mL}$ of $1000 \mathrm{ppm}$ potassium (stock solution) was added to a $100 \mathrm{~mL}$ volumetric flask and then added demineralized water right to mark boundaries, the obtained standard potassium $50 \mathrm{ug} / \mathrm{mL}$. Each of $2 \mathrm{~mL}, 4 \mathrm{~mL}, 6 \mathrm{~mL}, 8 \mathrm{~mL}$, and $10 \mathrm{~mL}$ pipette potassium standard solution pipetted $50 \mu \mathrm{g} / \mathrm{mL}$ in a $50 \mathrm{~mL}$ volumetric flask to obtain successive concentration of $2 \mu \mathrm{g} / \mathrm{mL}, 4 \mu \mathrm{g} / \mathrm{mL}, 6 \mu \mathrm{g} / \mathrm{mL}, 8 \mu \mathrm{g} / \mathrm{Ml}$, and $10 \mu \mathrm{g} / \mathrm{mL}$ and measured by atomic absorption spectrophotometry at a wavelength of $766.5 \mathrm{~nm}$. The absorbance obtained plotted with concentrations and then calculated the regression equation, regression coefficient $\left(\mathrm{R}^{2}\right)$, and correlation coefficient (R) of potassium.

\section{Preparation of calcium linearity}

A total of $5 \mathrm{~mL}$ of $1000 \mathrm{ppm}$ calcium (stock solution) was added to a $100 \mathrm{~mL}$ volumetric flask and then added demineralized water right to mark boundaries, obtained potassium with concentration $50 \mu \mathrm{g} / \mathrm{mL}$. Each of $2 \mathrm{~mL}, 4 \mathrm{~mL}, 6 \mathrm{~mL}, 8 \mathrm{~mL}$, and $10 \mathrm{~mL}$ pipetted calcium standard solution $50 \mu \mathrm{g} / \mathrm{mL}$ in a $50 \mathrm{~mL}$ volumetric flask to obtain successive concentration of $2 \mu \mathrm{g} / \mathrm{mL}, 4 \mu \mathrm{g} / \mathrm{mL}, 6 \mu \mathrm{g} / \mathrm{mL}, 8 \mu \mathrm{g} / \mathrm{mL}$, and $10 \mu \mathrm{g} / \mathrm{mL}$ and measured by atomic absorption spectrophotometry at a wavelength of $422.7 \mathrm{~nm}$. The absorbance obtained (Y) plotted versus concentrations $(\mathrm{X})$ and then calculated the regression equation, regression coefficient $\left(\mathrm{R}^{2}\right)$, and correlation coefficient $(\mathrm{R})$ of calcium.

Determination of potassium and calcium levels in extract solution Pipetted $1 \mathrm{~mL}$ from the sample solution and put into a $100 \mathrm{~mL}$ volumetric flask, then added with the demineralized water up to the mark line. Filtered with Whatmann filter paper Number 42, and discarded $5 \mathrm{~mL}$ of the first filtrate to saturate the filter paper. Then, the filtrate was collected into the bottle and measured the absorbance of the sample solution that has been prepared using flame atomic absorption spectrophotometry at a wavelength $766.5 \mathrm{~nm}$ for potassium and $422.7 \mathrm{~nm}$ for calcium. Absorbance values obtained should be within the range of the linearity range of potassium and calcium standard solurion. Levels of potassium and calcium are calculated based on the regression equation of the linearity data.

\section{RESULTS AND DISCUSSION}

\section{Potassium and calcium linearity}

Both of potassium and calcium linearity measured with the same range of concentration which was measured on concentration of $2 \mu \mathrm{g} / \mathrm{mL}$, $4 \mu \mathrm{g} / \mathrm{mL}, 6 \mu \mathrm{g} / \mathrm{mL}, 8 \mu \mathrm{g} / \mathrm{mL}$, and $10 \mu \mathrm{g} / \mathrm{mL}$, but the absorbance of potassium measured with $766.5 \mathrm{~nm}$ and the absorbance of potassium measured with $766.5 \mathrm{~nm}$ and calcium measured with $422.7 \mathrm{~nm}$. Table 1 shows the linearity curve data for potassium standard solution and calcium standard solution.

The correlation coefficient obtained for potassium and calcium can be accepted which should not smaller than 0.995 as the appropriate requirements for the correlation coefficient. Correlation coefficient of potassium and calcium obtained from the results suggested a linear relationship between the concentration and absorbance $[9,10]$.

\section{Solubility of calcium oxalate in breadfruit leaf extract solution}

The solubility test of calcium oxalate by the breadfruit leaf extract solution was conducted to determine the potential of early antinephrolithiasis effect by immersing $50 \mathrm{mg}$ of calcium oxalate in $50 \mathrm{~mL}$ of $10 \% \mathrm{~W} / \mathrm{V}$ breadfruit leaf extract solution. The level of potassium and calcium solubility in extract solution results is presented in Table 2 .

Based on the above results, it can be seen that the treatment with ethyl acetate extract gave the largest decrease in calcium content compared to n-hexane extract and ethanol extract. In addition, the three extracts showed that a decrease in potassium levels increased calcium levels after incubation with calcium oxalate, this is due to the fact that potassium is able to push the calcium from its bond with oxalate, so it becomes free calcium ions so that easy to remove through the urine $[11,12]$.

Ethyl acetate extract has the lowest potassium content among other extracts, but it can give the best dissolution effect of calcium oxalate. This may be caused by other phytochemical contents that play a role in the dissolution process of calcium oxalate. Since ethyl acetate is semi-polar, it is possible to have a semi-polar content of flavonoids contained in a sufficiently high amount in ethyl acetate extract. These flavonoids are thought to help improve the dissolving effect of calcium oxalate $[13,14]$.

Table 1: Linearity data for potassium standard solution and calcium standard solution

\begin{tabular}{lll}
\hline Number & Concentration $-X(\mu \mathrm{g} / \mathrm{mL})$ & Absorbance - Y \\
\cline { 2 - 3 } & & Potassium (K) \\
\hline 1 & 0.00 & 0.00000 \\
2 & 2.00 & 0.08039 \\
3 & 4.00 & 0.16052 \\
4 & 6.00 & 0.24131 \\
5 & 8.00 & 0.32039 \\
\hline
\end{tabular}




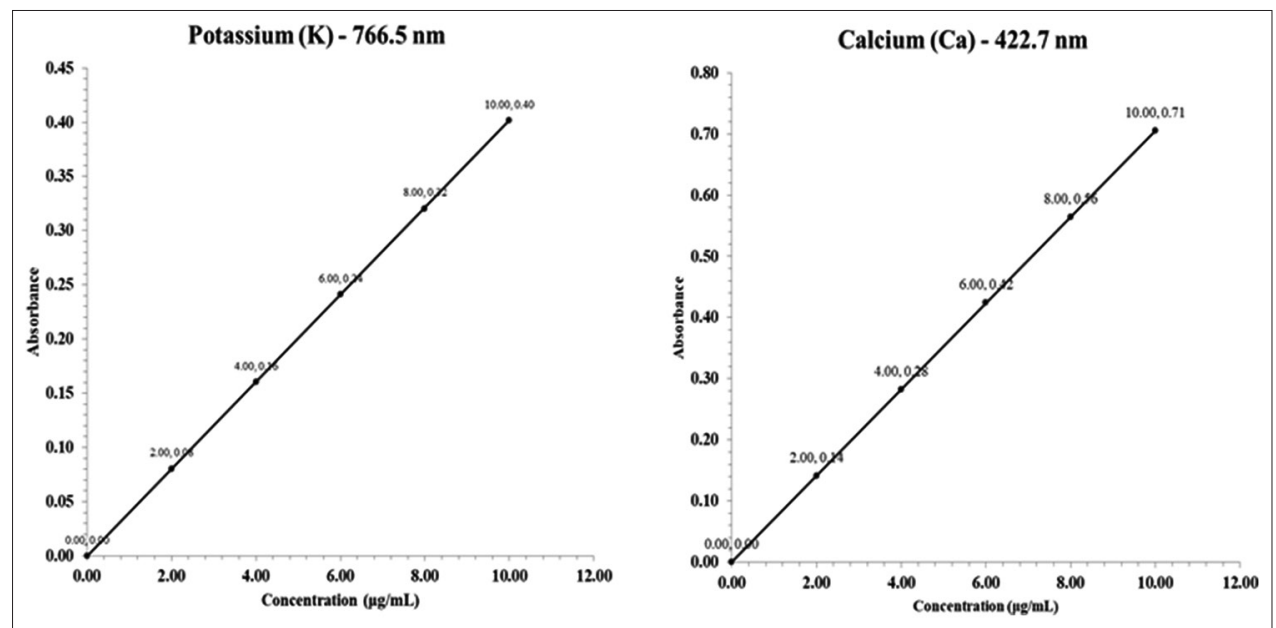

Fig. 1: Linearity of potassium standard solution and calcium standard solution

Table 2: Level of potassium and calcium solubility in extract solution

\begin{tabular}{|c|c|c|c|c|c|c|c|c|}
\hline \multirow[t]{2}{*}{ Number } & \multirow[t]{2}{*}{ Group } & \multicolumn{2}{|c|}{$\begin{array}{l}\text { Potassium level in } \\
\text { extract }(\mu \mathrm{g} / \mathrm{mL})\end{array}$} & \multicolumn{2}{|c|}{$\begin{array}{l}\text { Calcium level in } \\
\text { extract }(\mu \mathrm{g} / \mathrm{mL})\end{array}$} & \multirow{2}{*}{$\begin{array}{l}\text { Calcium level } \\
\text { in kidney } \\
\text { stone }(\mu \mathrm{g} / \mathrm{mL})\end{array}$} & \multicolumn{2}{|l|}{ solubility } \\
\hline & & $\begin{array}{l}\text { Before } \\
\text { incubation }\end{array}$ & $\begin{array}{l}\text { After } \\
\text { incubation }\end{array}$ & $\begin{array}{l}\text { Before } \\
\text { incubation }\end{array}$ & $\begin{array}{l}\text { After } \\
\text { incubation }\end{array}$ & & $(\mu \mathrm{g} / \mathrm{mL})$ & $(\%)$ \\
\hline 1 & A & 0.00 & 0.00 & 0.00 & 8.45 & 92.56 & 8.45 & 9.13 \\
\hline 2 & B1 & 4.05 & 2.02 & 21.21 & 35.77 & 93.56 & 14.56 & 15.56 \\
\hline 3 & B2 & 8.02 & 3.67 & 42.44 & 65.15 & 92.41 & 22.71 & 24.58 \\
\hline 5 & B4 & 15.79 & 7.54 & 82.71 & 129.90 & 92.83 & 47.19 & 50.83 \\
\hline 6 & B5 & 19.74 & 11.19 & 98.27 & 159.65 & 91.92 & 61.38 & 66.78 \\
\hline 7 & $\mathrm{C} 1$ & 2.11 & 1.95 & 17.21 & 60.88 & 92.76 & 43.67 & 47.08 \\
\hline 8 & $\mathrm{C} 2$ & 4.15 & 3.92 & 32.18 & 87.47 & 93.18 & 55.29 & 59.34 \\
\hline 9 & $\mathrm{C} 3$ & 6.28 & 6.02 & 50.14 & 116.44 & 93.45 & 66.30 & 70.95 \\
\hline 10 & $\mathrm{C} 4$ & 8.39 & 8.08 & 66.15 & 140.97 & 92.88 & 74.82 & 80.56 \\
\hline 11 & $\mathrm{C} 5$ & 10.50 & 10.11 & 82.54 & 164.78 & 92.47 & 82.24 & 88.94 \\
\hline 12 & D1 & 2.45 & 1.25 & 7.51 & 17.11 & 92.75 & 9.60 & 10.35 \\
\hline 15 & D4 & 9.75 & 8.01 & 30.62 & 54.47 & 91.94 & 23.85 & 25.94 \\
\hline 16 & D5 & 12.28 & 10.01 & 40.91 & 69.30 & 92.55 & 28.39 & 30.68 \\
\hline
\end{tabular}

\section{CONCLUSION}

Breadfruit leaf ethyl acetate extract solution gives the highest antinephrolithiasis effect than breadfruit leaves n-hexane extract solution and breadfruit leaf ethanol extract solution. This is due to the high content of flavonoids and potassium in the breadfruit leaf ethyl acetate extract, allowing flavonoids and potassium to break the bond between calcium with oxalic (in calcium oxalate) and calcium with carbonic (in calcium carbonate). It is hoped that subsequent studies continue the in vivo antinephrolithiasis effects of breadfruit leaf extract.

\section{ACKNOWLEDGEMENT}

The authors acknowledge the financial support by Research Institutions, University of Sumatera Utara, in accordance with the Contract Research TALENTA University of Sumatera Utara, Fiscal Year 2017, Number: 5338 / UN5.1.R / PPM / 2017 on 22 May 2017.

\section{AUTHOR'S CONTRIBUTIONS}

This work was carried out in collaboration between all authors. Effendy De Lux Putra designed the research, Nahitma Ginting and Nazliniwaty supervise the research, and Iksen, Erik Kurniawan, and Nerdy did the research work, collected the data, and analyzed the data.

\section{CONFLICT OF INTERESTS}

The authors declare that they have no conflicts of interests.

\section{REFERENCES}

1. Kamal Z, Suparmi S, Sumarmi S. Identification and Determination of Dissolved Calcium Levels in Cat Whiskers (Orthisiphon aristatus) Water Fraction and Ethyl Acetate Fraction by Atomic Absorption Spectrophotometry. Vol. 1. Proceedings of the Scientific Meeting and Presentation of Basic Research on Nuclear Science and Technology 2013. p. 363-8.

2. Chikezie PC, Ojiako OA. Herbal medicine: Yesterday, today and tomorrow. Altern Integr Med 2015;4:1-5.

3. Guinnin FFD, Klotoe JR, and Ategbo JM. Acute Toxicity Evaluation of Ethanolic Extract of Aristolochia albida Duch. Leaves on Wistar Rats Liver and Kidney Functions. Int J Pharm Pharm Res 2017;9(7):35-40.

4. Bouhalit S, Kechrid, Z, and Elfeki A. Effect of Silymarin Extracted from Silybum marianum on Nickel Hematotoxicity and Nephrotoxicity in Male Albino Wistar Rats. Int J Pharm Pharm Res 2017;9(8):84-89.

5. Mardiana L. Miracle Leaf Treating Disease. Jakarta: Penebar Swadaya; 2012. p. 28.

6. Arifin HN, Muchtar H. Efek Diuretik dan Daya Larut Batu Ginjal Dari Ekstrak Etanol Rambut Jagung (Zea mays L.). Prosiding Seminar Nasional Perkembangan Terkini Sains Farmasi dan Klinik III; 2013.

7. Winston D. Herbal and Nutritional Treatment of Kidney Stones. J Am Herb Guild 2011;10:61-9.

8. Pearle MS, Calhoun EA, Curhan GC. Uroligic Diseases in America. Washington: US Government Publishing Office; 2004. p. 7.

9. Gandjar IG, Rohman A. Pharmaceutical Chemistry Analysis. $3^{\text {rd }}$ ed. Yogyakarta: Pustaka Pelajar; 2008. p. 305-19.

10. Harmita. Method Validation Guidance and the Calculation. Majalah Ilmu Kefarmasian 2004;1:117-30. 
11. Haro GI, Sinaga SM. In vitro test of chive leaves infuse (Allium schoenoprasum, L.) on calcium oxalate solubility using atomic absorption spectrophotometry. Int J Chemtech Res 2016;10:99-102.

12. Amin B, Feriz HM, Hariri AT, Meybodi NT, Hosseinzadeh H. Protective effects of the aqueous extract of Crocus sativus against ethylene glycol induced nephrolithiasis in rats. EXCLI J 2015;14:411-22.
13. Hadjzadeh MA, Nama M, Zeynab R, dan Fatemeh BR. Effect of Tyymoquinone on ethylene glycolinduced kidney Calculi in Rats. Urol J 2008;5:149-55.

14. Saha S, Verma RJ. Bergenia ciliata extract prevents ethylene glycol induced histopathological changes in the kidney. Acta Pol Pharm $2011 ; 68: 711-5$ 